\title{
Histamine-releasing activity and bronchoconstricting effects of sisal
}

\author{
P. J. NICHOLLS, ELIZABETH EVANS, F. VALIC, \\ and EUGENIJA ŽUŠKIN \\ Welsh School of Pharmacy, UWIST, Cardiff, UK, and Andrija Štampar School \\ of Public Health, Zagreb University, Zagreb, Yugoslavia
}

\begin{abstract}
Nicholls, P. J., Evans, E., Valić, F., and Žuškin, E. (1973). British Journal of Industrial Medicine, 30, 142-145. Histamine-releasing activity and bronchoconstricting effects of sisal. Extracts of dry and oiled sisal released histamine from pig and human but not from rat lung tissue. A suspension in Tyrode solution of the oil used for softening the sisal fibres had a $\mathrm{pH}$ of 8.1 and also released histamine from pig and human lung. The releasing activity was abolished when the $\mathrm{pH}$ of this suspension was adjusted to $\mathrm{pH} 7 \cdot 4$. As all the sisal extracts were adjusted to $\mathrm{pH} \mathbf{7 \cdot 4}$ for incubation with lung tissue, the histamine-releasing activity of sisal in vitro is unrelated to the presence of the oil.

Significant $(P<0.01)$ mean reductions over the work shift of ventilatory capacity (PEF and $\mathrm{FEV}_{1 \cdot 0}$ ) were recorded in all the workers exposed to airborne sisal dust. These reductions were greater in combers than in drawers and spinners. Sisal collected from combing machines possessed more histamine-releasing activity than material from drawing and spinning machines.

These results indicate that histamine release by sisal may be the cause of acute ventilatory capacity changes in sisal exposure.
\end{abstract}

Our previous study of respiratory symptoms in sisal workers has shown that sisal dust causes acute reductions of ventilatory capacity over the work shift (Žuškin, Valić, Nicholls, and Evans, 1972).

Evidence has been collected that changes in ventilatory capacity during exposure to cotton dust in humans are due partly at least to the release of histamine in the lungs (Nicholls, Nicholls, and Bouhuys, 1967; Edwards et al., 1970). Extracts of sisal have been found to contain a smooth muscle contractor (Nicholls, 1962) but not to release histamine from the rat tissues (Subiza, Alizo, and Diaz, 1970). The present study was undertaken to reexamine whether sisal possesses histamine-releasing activity and to establish whether acute ventilatory changes observed over a work shift are related to this activity of the sisal dust to which the workers are exposed.

\section{Population, materials, and methods}

A total of 51 non-smoking female workers employed in a work room of a small sisal processing plant in Yugoslavia were surveyed. They worked on drawing, combing, and spinning machines. The mean age of combers was 27 (range 22-37) years and the mean age of drawers and spinners was 28 (range 19-42) years. The mean height of combers was $160 \mathrm{~cm}$ (range $151-168 \mathrm{~cm}$ ) and that of drawers and spinners $160 \mathrm{~cm}$ (range $153-171 \mathrm{~cm}$ ). The mean duration of the combers' exposure to sisal dust was 5 (range 1-7) years and that of drawers and spinners 5 (range 1-10) years.

Samples of sisal (imported from Pakistan) for biochemical analysis were collected from the combing, drawing, and spinning machines. The raw dry sisal fibres were analysed as well as the oiled fibres collected on the machines before processing. For biochemical analyses the fibres were cut with scissors into small pieces. A sample of the native oil used for softening the fibres 
was also analysed. For comparative purposes, cardroom dust from an English cotton mill spinning coarse-grade cotton was analysed. The synthetic histamine releaser, compound 48/80, was purchased from Burroughs Wellcome and Co., England.

The one-second forced expiratory volume $\left(\mathrm{FEV}_{1 \cdot 0}\right)$ was measured with Bernstein type spirometers, and the peak expiratory flow (PEF) with Wright peak flow meters (Wright and McKerrow, 1959). Ventilatory function tests were performed at the beginning and the end of the first work shift after two days of absence from work. The mean of the two highest values of five recordings was used as the result of the test.

Total and respirable airborne dust samples were collected by means of modified Hexhlet two-stage samplers. The respirable dust fraction is defined as the particle size fraction that passes the horizontal laminal plate elutriator constructed in conformity with the requirements adopted at the Johannesburg International Pneumoconiosis Conference for particle retention in the upper respiratory tract (Orenstein, 1960).

For biochemical analysis the vegetable dust extracts were prepared by grinding the finely cut sisal or cotton dust $(1 \mathrm{~g})$ with Tyrode solution $(6 \mathrm{ml})$, as described by Nicholls (1962). The pH of these extracts $(7 \cdot 2-7 \cdot 8)$ was adjusted to 7.4 before incubation with lung tissue. The histamine content of the extracts was determined spectrophotofluorimetrically (Shore, Burkhalter, and Cohn, 1959). Pig lung was obtained from an abattoir and human lung from surgical lung resection. In all instances the lung was used within two hours of its removal. Incubation of the extracts of lung tissue and determination of the histamine release were performed after the technique described by Nicholls et al. (1967), except that the lung was chopped into rods of $0.31 \mathrm{~mm}^{2}$ crosssectional area by means of a McIlwain tissue chopper and that $100 \mathrm{mg}$ of the tissue was employed for each incubation flask. The oil $(300 \mathrm{mg})$ was shaken with Tyrode solution $(6 \mathrm{ml})$ and the resulting suspension $(1.5 \mathrm{ml} /$ flask) was used for incubation with lung. In one experiment 5-g samples of sisal fibres were extracted with diethyl-ether in a Soxhlet apparatus to remove the oil. Extracts of the oil-free fibres and suspensions of the ether-extractable oil were prepared as described above.

\section{Results}

No histamine was detected in any of the sisal samples. The oil used for softening the fibres did not interfere with the assay.

When incubated with rat lung, neither the sisal nor the cotton dust extracts caused a release of histamine. In contrast, compound $48 / 80$ released a substantial quantity of this amine (Table 1). The extracts of all the sisal fibre samples released significant amounts of histamine from pig and human lung on incubation (Table 1). While the results varied from experiment to experiment, the general trend was similar and sisal from the spinning and drawing machines appeared to possess slightly less histamine-releasing activity on human lung than fibre from other areas of the factory. It is also evident that the activity of sisal is less than that of cotton dust.

The histamine-releasing activity was not significantly altered by Soxhlet extraction of oil and other lipophilic material from sisal with ether (Table 1). The ether-soluble fraction (an oil) extracted from the oiled sisal fibres amounted to $0.2,0.4$, and $0.3 \mathrm{~g} / \mathrm{g}$ of fibre for material from the combing, drawing, and spinning machines respectively. Based on the mean value $(0.3 \mathrm{~g} / \mathrm{g})$, these

TABLE 1

Histamine ReleAse from Lung Tissue in Vitro

\begin{tabular}{|c|c|c|c|c|c|c|c|c|c|c|}
\hline & \multirow{3}{*}{\multicolumn{2}{|c|}{ Lung }} & & \multirow{3}{*}{$\begin{array}{l}\text { Histamine content } \\
\text { of lung }(\mu \mathrm{g} / \mathrm{g})\end{array}$} & \multicolumn{6}{|c|}{ Proportion (\%) of histamine released from lung by } \\
\hline & & & & & \multicolumn{4}{|c|}{ Sisal } & \multirow{2}{*}{ Cotton dust } & \multirow{2}{*}{$48 / 80$} \\
\hline & & & & & Dry & Combing & Drawing & Spinning & & \\
\hline \multicolumn{4}{|c|}{ Rat } & $8 \cdot 3$ & 0 & 0 & 0 & $\mathbf{0}$ & $\mathbf{0}$ & $11 \cdot 1$ \\
\hline Pig & : & $\begin{array}{l}. \\
\cdots \\
\cdots \\
\cdots \\
.\end{array}$ & $\begin{array}{l}\ldots \\
\cdots \\
\ldots \\
\ldots\end{array}$ & $\begin{array}{r}74 \cdot 2 \\
48 \cdot 2 \\
62 \cdot 5 \\
164 \cdot 8 \\
54 \cdot 0\end{array}$ & $\begin{array}{l}2 \cdot 9 \\
3 \cdot 2 \\
0 \cdot 4 \\
3 \cdot 2 \\
4 \cdot 6\end{array}$ & $\begin{array}{r}3.6 \\
12.7 \\
1.2 \\
4.9 \\
3.7\end{array}$ & $\begin{array}{l}3.5 \\
6.2 \\
1.4 \\
3.9 \\
8.5\end{array}$ & $\begin{array}{c}1 \cdot 7 \\
4 \cdot 6 \\
0 \\
5 \cdot 6 \\
5 \cdot 2\end{array}$ & $\begin{array}{l}9.9 \\
4.9 \\
4.9 \\
7.0 \\
8.9\end{array}$ & $\begin{array}{c}14 \cdot 1 \\
16 \cdot 0 \\
- \\
-\end{array}$ \\
\hline Man & & $\begin{array}{l}. \\
\ldots\end{array}$ & $\begin{array}{l}. \\
\ldots\end{array}$ & $\begin{array}{l}32 \cdot 8 \\
25 \cdot 1\end{array}$ & $\begin{array}{l}1 \cdot 7 \\
2 \cdot 9\end{array}$ & $\begin{array}{l}9 \cdot 1 \\
4 \cdot 8\end{array}$ & $\begin{array}{l}1.2 \\
2.7\end{array}$ & $\begin{array}{c}0 \\
0.5\end{array}$ & $\begin{array}{r}13 \cdot 2 \\
9.6\end{array}$ & $\overline{12 \cdot 0}$ \\
\hline
\end{tabular}

Lung tissue $(100 \mathrm{mg})$ was incubated at $37^{\circ} \mathrm{C}$ for $25 \mathrm{~min}$ in Tyrode solution $(3 \mathrm{ml}) \mathrm{pH} \mathrm{7.4}$ which contained either compound $48 / 80(100 \mu \mathrm{g})$ or the soluble material from $250 \mathrm{mg}$ of sisal fibre or cotton dust. The histamine released is expressed as a percentage of the histamine content of the lung sample. Each value is the mean of two results. Blank spaces in the table indicate that no determination was made.

${ }^{1}$ Sisal samples for this experiment had been extracted with ether prior to extraction with Tyrode solution. 
extracted oils were suspended in Tyrode solution at a concentration $(50 \mathrm{mg}$ oil $/ \mathrm{ml})$ equivalent to that which would be obtained by extracting oiled fibre $(1 \mathrm{~g})$ with Tyrode solution $(6 \mathrm{ml})$. These suspensions,

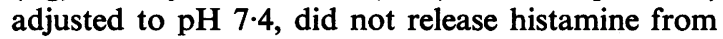
pig or human lung when incubated in vitro.

A suspension of the native oil in Tyrode solution $(50 \mathrm{mg} / \mathrm{ml})$ was also prepared. This had a $\mathrm{pH}$ of $8 \cdot 1$. When this suspension was incubated with pig and human lung, histamine was released to the extent of $3.4 \pm 0.5 \%$ and $8.2 \%$ (mean of 2 experiments) respectively. Tyrode solution, $\mathrm{pH} 8 \cdot 1$, did not possess any histamine-releasing activity. The releasing activity of the suspension of native oil was abolished by adjusting the $\mathrm{pH}$ to $\mathbf{7 \cdot 4}$. In relation to these effects, it was found that histamine was released from pig lung $(2.5 \%, 1$ experiment) by a suspension of the ether-soluble material from oiled sisal (drawing machine) adjusted to $\mathrm{pH} 8 \cdot 1$.

As shown in Table 2 , significant $(P<0.01)$ acute reductions in both mean PEF and $\mathrm{FEV}_{1.0}$ were recorded in combers as well as in drawers and spinners over the working shift. The reductions were higher in combers (PEF - $331 / \mathrm{min} ; \mathrm{FEV}_{1 \cdot 0}$ $-145 \mathrm{ml}$ ) than in drawers and spinners (PEF - 26 $1 / \mathrm{min} ; \mathrm{FEV}_{1.0}-111 \mathrm{ml}$ ) but these differences were not statistically significant $(P>0.05)$. The sisal workers were divided into these two groups because of the location of combing machines in one part of the work room and drawing and spinning machines in the other. The mean concentrations of airborne sisal dust were practically the same in both parts of the work room (spinning and drawing area: 1.84 $\mathrm{mg} / \mathrm{m}^{3}$ total, $0.74 \mathrm{mg} / \mathrm{m}^{3}$ respirable; combing area: $1.96 \mathrm{mg} / \mathrm{m}^{3}$ total, $0.67 \mathrm{mg} / \mathrm{m}^{3}$ respirable).

\section{Discussion}

The present work confirms the findings of Subiza et al. (1970) that sisal does not release histamine from rat tissues. However, of greater significance is the ability of sisal to release histamine from human lung tissue. This action could account for the effects of inhaled sisal particles upon respiratory mechanics.

It would appear that the ability of the oil used to soften sisal fibres to release histamine is dependent on the $\mathrm{pH}$ of the incubation medium. The histaminereleasing activity exhibited by the sisal extracts in these in vitro experiments is not due to the oil as all incubations were carried out at $\mathrm{pH} 7 \cdot 4$. At this $\mathrm{pH}$ the oil is not an active releasing agent. In addition, the sisal fibres retained their activity after the oil had been removed by ether. This latter fact indicates that the histamine-releasing substance of sisal is not lipophilic. However, when oiled sisal particles are inhaled, it is possible that the oil may contribute to the histamine-releasing action of this material in the respiratory tract as the secretions of the bronchial tree may not effectively neutralize the oil. It may be prudent, therefore, to replace this type of oil by one without histamine-releasing activity. The histamine releasers, $48 / 80$ and sinomenine, have been shown to release histamine by a physicochemical mechanism at alkaline $\mathrm{pH}$ in vitro (Yamasaki and Endo, 1967) and it is possible that the oil used for sisal fibres may contain a substance acting by a similar mechanism.

The results presented in Table 1 show that the sisal collected in the combing area exhibited a greater histamine-releasing activity on human lung than that collected in the drawing and spinning areas. The acute reductions of ventilatory capacity were found to be greater in combers than in drawers and spinners (Table 2). If the acute ventilatory capacity changes are the consequence of the effect of the released histamine, then this was to be expected. However, because the differences were not significant, probably owing to the small number of the workers available and their short duration of exposure, the results are not conclusive. Yet the results do indicate that histamine release plays a role in the development of the acute changes of ventilatory capacity of sisal workers. It has been shown that in hemp workers the acute fall of

TABLE 2

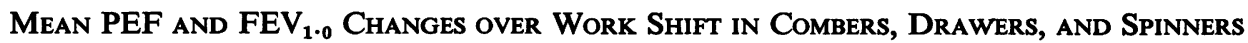

\begin{tabular}{|c|c|c|c|c|c|c|c|}
\hline Test & Group & $N$ & $\begin{array}{c}\text { Before shift } \\
1\end{array}$ & $\begin{array}{l}\text { After shift } \\
2\end{array}$ & $\begin{array}{l}\text { Difference } \\
2-1\end{array}$ & $P$ & $\begin{array}{c}\text { Preshift values } \\
\text { as } \% \text { of expected } 1\end{array}$ \\
\hline $\begin{array}{l}\text { PEF } \\
(1 / \mathrm{min})\end{array}$ & $\begin{array}{l}\text { Combers } \quad . . \\
\text { Drawers and spinners.. }\end{array}$ & $\begin{array}{l}12 \\
39\end{array}$ & $\begin{array}{l}407 \\
427\end{array}$ & $\begin{array}{l}374 \\
401\end{array}$ & $\begin{array}{l}-33(-8.1 \%) \\
-26(-6.1 \%)\end{array}$ & $\begin{array}{l}<0.01 \\
<0.01\end{array}$ & $\begin{array}{l}105 \cdot 71 \\
110 \cdot 62\end{array}$ \\
\hline $\begin{array}{l}\mathrm{FEV}_{1 \cdot 0} \\
(\mathrm{ml})\end{array}$ & $\begin{array}{l}\text { Combers } \quad \ldots \\
\text { Drawers and spinners. . }\end{array}$ & $\begin{array}{r}129 \\
39\end{array}$ & $\begin{array}{l}2929 \\
3070\end{array}$ & $\begin{array}{l}2784 \\
2959\end{array}$ & $\begin{array}{l}-145(-5.0 \%) \\
-111(-3.6 \%)\end{array}$ & $\begin{array}{l}<0.01 \\
<0.01\end{array}$ & $\begin{array}{r}97.40 \\
101.99\end{array}$ \\
\hline
\end{tabular}

'The preshift $\mathrm{FEV}_{1 \cdot 0}$ values were compared with the expected $\mathrm{FEV}_{1 \cdot 0}$ obtained from the Veterans Administration-Army Cooperative Study nomogram for normal females (Kory, Smith, and Callahan, in preparation). The predicted PEF values were calculated from the nomogram for the healthy female population of Ferris, Anderson, and Zickmantel (1965). 
ventilatory capacity could be at least partially prevented by the preshift administration of an antihistamine, indicating that this fall is due partly to the effect of histamine release (Valić and Žuškin, 1972). An identical study of a possible preventive effect of an antihistamine drug in sisal dust exposure is in progress.

P.J.N. is in receipt of a grant from the British Medical Research Council.

Reprint requests to P. J. Nicholls, Welsh School of Pharmacy, UWIST, Cardiff, CF13NU, Wales, UK.

\section{References}

Edwards, J., McCarthy, P., McDermott, M., Nicholls, P. J., and Skidmore, J. W. (1970). The acute physiological, pharmacological and immunological effects of inhaled cotton dust in normal subjects. Journal of Physiology, 208, 63P.

Ferris, B. G., Anderson, D. O., and Zickmantel, R. (1965). Prediction values for screening tests of pulmonary function. American Review of Respiratory Diseases, 91, 252-261.

Nicholls, P. J. (1962). Some pharmacological actions of cotton dust and other vegetable dusts. British Journal of Industrial Medicine, 19, 33-41.

-, Nicholls, G. R., and Bouhuys, A. (1967). Histamine release by Compound $48 / 80$ and textile dusts from lung tissue in vitro. In Inhaled Particles and Vapours, II, edited by C. N. Davies, pp. 69-74. Pergamon, Oxford.
Orenstein, A. J. Editor (1960). Proceedings of the Pneumoconiosis Conference, Johannesburg, 1959. Churchill, London.

Shore, P. A., Burkhalter, A., and Cohn, V. H. (1959). A method for the fluorimetric assay of histamine tissues. Journal of Pharmacology and Experimental Therapeutics, 127, 182-186.

Subiza, E., Alizo, P., and Diaz, P. (1970). Estudios experimentales del contenido en histamina ye efecto histaminoliberador del sisal, Bagazo, Canamo, Algodon y Madera de Ukola (Dumoria Africana). Proceedings of Second International Conference on Respiratory Diseases in Textile Workers, Alicante, Spain, 30 September to 2 October, 1968, pp. 110-127.

Valić, F., and Žuškin, E. (1972). Prevention of acute ventilatory capacity reduction in hemp workers by antihistaminic, bronchodilator and vitamin C. Abstracts of XVII International Congress on Occupational Health, Buenos Aires, 17-23 September, 1972, pp. 108-109.

Wright, B. M., and McKerrow, C. B. (1959). Maximum forced expiratory flow rate as a measure of ventilatory capacity, with a description of a new portable instrument for measuring it. British Medical Journal, 2, 1041-1047.

Yamasaki, H., and Endo, K. (1967). Coexistence of energy dependent and non-dependent processes in histamine release mechanism of compound $48 / 80$ and sinomenine: Experiments on chopped skin from various animal species. Japanese Journal of Pharmacology, 17, 228-239.

Žuškin, E., Valió, F., Nicholls, P. J., and Evans, E. (1972). Respiratory symptoms and ventilatory function in sisal dust exposure. Internationales Archiv für Arbeitsmedizin, 30, $105-111$.

Received for publication April 4, 1972.

Accepted for publication August 7, 1972. 